Old Dominion University ODU Digital Commons

2014

\title{
Crime and Natural Resource Booms: Evidence From Unconventional Natural Gas Production
}

Timothy M. Komarek

Old Dominion University, tkomarek@odu.edu

Follow this and additional works at: https://digitalcommons.odu.edu/economics_facpubs

Part of the Business Commons, Criminology Commons, and the Social Control, Law, Crime, and Deviance Commons

\section{Repository Citation}

Komarek, Timothy M., "Crime and Natural Resource Booms: Evidence From Unconventional Natural Gas Production" (2014).

Economics Faculty Publications. 29.

https://digitalcommons.odu.edu/economics_facpubs/29

\section{Original Publication Citation}

Komarek, T. M. (2014). Crime and natural resource booms: Evidence from unconventional natural gas production. The Annals of Regional Sciences, 1-25. doi:10.1007/s00168-018-0861-x 


\title{
Crime and Natural Resource Booms: Evidence from Unconventional Natural Gas Production
}

\begin{abstract}
By TIMOTHY M. KoMAREK *
The United States has experienced a sudden expansion of natural gas production due to the combination of hydraulic fracturing and horizontal drilling. The energy extraction boom will likely have localized impacts, most notably in areas with substantial shale gas reserves. This paper exploits a natural experiment in the Marcellus region to examine one channel of the so-called 'resource curse,' the effect of resource extraction on local crime. The results show that areas experiencing a natural gas extraction boom suffer a significant increase in overall violent crimes, while property crimes remain similar to non-boom areas. Furthermore, the violent crime increase appears to be driven primarily by increases in aggravated and sexual assaults.
\end{abstract}

Keywords: boomtown, crime, resource extraction, Marcellus shale, panel data, natural experiment

* Komarek: Old Dominion University, 2023 Constant Hall Norfolk, VA 23529 (e-mail: tkomarek@odu.edu) 
In the 2000s the United States began experiencing a boom in natural gas production. Estimates from the Energy Information Administration (EIA) indicate production increased by over $25 \%$ from 2000 to 2013 . The sudden expansion of natural gas was largely due to new technologies combining horizontal drilling and hydraulic fracturing ${ }^{1}$ (a.k.a. fracking). Specifically, advances in fracking technology have made it profitable to extract natural gas from shale formations ${ }^{2}$, which were previously inaccessible. The EIA 2013 Annual Energy Outlook predicts natural gas production will continue to rise with estimates suggesting U.S. reserves hold 70 years of natural gas supply. The natural gas boom will likely have broad impacts on issues ranging from energy security to climate change. However, the energy boom will also impact local communities, or 'boomtowns' where extraction takes place.

There is a large literature examining the effect of resource extraction and specialization on economic growth and the labor market. First, resource extraction could create short-run benefits through spillovers in the multiplier process (e.g. income and jobs). The income multiplier development channel is likely to be relevant for shale gas production due to the potential financial windfall to landholders from mineral right leasing (Paredes et al. 2015). While the "resource curse" literature highlights that some industries and residents could be harmed over time through the extraction industry bidding up factor prices, ${ }^{3}$ among other issues (Corden and Neary 1982, Sachs and Warner 2001, Jacobsen and Parker, 2014). Nonetheless, the previous literature has found little evidence of the socalled "resource curse" in the fracking boom (Weber 2014, Brown 2014).

Media outlets have also begun to draw attention to a darker side of the fracking

${ }^{1}$ See Fitzgerald (2013) for a non-technical description of hydraulic fracturing

${ }^{2}$ Maps of unconventional shale reserves are available from the Energy Information Administration:

http://www.eia.gov/pub/oil_gas/natural_gas/analysis_publications/maps/maps.htm

${ }^{3}$ This version of the "resource curse" has been labeled "Dutch disease" 
boom. For example, an article in National Geographic on the Bakken Shale area of North Dakota highlights binge drinking, prostitution, and violence among other negative behaviors due to the "man camps" that spring up to house outside workers (Dobbs 2013). Journalists have also noted increases in drugs and drug related crimes in the Washington Post (Horwitz 2014), violence against women in the New York Times (Eligon 2013), as well as fatal accidents and sexually transmitted infections (Food and Water Watch, 2013). In a revealing exposition titled "Wildcatting: A Stripper's Guide to the Modern American Boomtown" an adult entertainment worker describes her "roughneck" customers and the transition of Williston, N.D. into a resource extraction boomtown (Shepard 2013). The author writes:

Williston residents complain that an unsavory element has been drawn to town, pointing to spikes in violent crime, sexual assault, and drugrelated (often meth) arrests. In March, a man was murdered in the street in front of the two strip clubs. A brawl in Heartbreakers spilled into the street. It was possibly spurred along by one of the Heartbreakers bouncers. A man was shot and killed. The police didn't arrive for 30 minutes because the on-duty officers were tied up at another (non-lethal) shooting on the other side of town. The phrase "the Wild West" is frequently uttered; to many it feels lawless.

The author describes the population growth in the boomtown, which largely comes from young males earning a high salary with little attachment to the community. This echoes academic research (e.g. Archbold, 2013, Ruddell, 2011) suggesting the inability of the local government, including law enforcement, to respond to rapidly changing local conditions in boomtowns.

The resource curse literature, which often examines resource rich countries, includes rent seeking, corruption and conflict as channels that perpetuate poor overall growth prospects (Van der Ploeg 2011). However, the research on the localized effect of a resource boom on criminal activity in a developed country is 
scarce. For example, the criminology literature has utilized qualitative methods to show increased fear of crime and drunk driving among local residents as a result resource based booms (Carrignton Pereira 2011, Ruddell et al. 2013). While Luthra et al. (2007) use pooled time-series analysis for the offshore oil industry in Louisiana, but do not significant effects on local crime. In contrast, Haggerty et al. (2014) find that specialization in oil and gas extraction in the 1970s negatively effected crime rates (property and violent) and education rates long-term. This work quantifies the negative effects of the resource bust on crime and quality of life indicators.

The objective of this study is to examine the effect of unconventional ${ }^{4}$ (fracking) natural gas extraction, and more generally resource booms, on crime in a community. Social costs associated with resource extraction are an important, yet less understood component of the resource curse. I use county level data from 2004 - 2012 on seven FBI Index I offenses and unconventional natural gas wells drilled. My identification strategy exploits a natural experiment resulting from differing policies related to fracking in the Marcellus region. In particular, the State of New York until recently imposed a moratorium on using fracking techniques (Rabe and Borick 2013). Conversely, the Commonwealth of Pennsylvania permitted use of fracking technology over the sample time period. The natural experiment provides an arguably exogenous variation in policy regimes, because the New York moratorium was largely due to environmental concerns, and not the fear of increased criminal activity. ${ }^{5}$ My results show that natural gas boom counties (measured by 75 or more unconventional wells drilled

\footnotetext{
4 "An unconventional gas well is a well that is drilled into an unconventional formation, which is defined as a geologic shale formation below the base of the Elk Sandstone or its geologic equivalent where natural gas generally cannot be produced except by horizontal or vertical well bores stimulated by hydraulic fracturing." (Pennsylvania Department of Environmental Protection SPUD Data Report)

5 For example, the fracking opposition group "New Yorkers Against Fracking" focuses on ground water contamination issues. More information found at: http://nyagainstfracking.org
} 
in a year) experience a more than $30 \%$ increase in violent crimes compared to control counties. In contrast, property crimes in boom counties were statistically insignificant in my preferred specification. Falsification tests provide no evidence that the positive relationship between fracking and crime is due to divergent preexisting trends, and therefore support a causal interpretation. I use data from the criminology literature to estimate the total victimization cost of $\$ 11.7$ million per boom county each year.

This study contributes to the literature in several ways. First, I measure the contemporaneous effect of natural resource extraction on criminal activity. Ideally, one would want to examine the effect of the influx of extraction workers on crime. However, labor market data is unreliable due to the transient nature of many extraction workers and censored industry classification information at the county level. Therefore, I consider boom areas based on the number of unconventional wells drilled. Inevitably humans commit and are victims of crimes, nonetheless unconventional wells drilled act as a proxy for economic activity from resource extraction. According to Jacquet (2009), the drilling phase is the most labor-intensive part of natural gas extraction. Thus, the time horizon I am measuring differs from Haggerty et al. (2014), which considers crime resulting from industry specialization and an energy extraction bust. Second, I discuss the various theoretical links from the economics and criminology literature on resource extraction and crime. Third, I demonstrate that my results are robust to the inclusion of a wide range of controls, such as area and time fixed effects, demographics and population change. Furthermore, I show that the results are robust to alternative specifications, samples and estimation techniques as well as provide an estimate of victimization costs from the criminology literature. 


\section{Resource Booms and Crime}

\section{A. Economic Impact of the Natural Gas Boom}

Corden and Neary (1982) and Jacobsen and Parker (2014) highlight the broader economic implications of a resource extraction boom and bust. During a resource boom an unanticipated labor demand shock is expected to increase wages for extraction workers as well as wages in related industries to attract workers $^{6}$. The ability of the local labor market to respond to the demand shock depends on the specialized needs in the resource extraction industry and the skills of local residents. Research on the coal boom in the 1970s suggests that local residents filled many low-skilled jobs (Black et al. 2005a, Black et al. 2005b). On the other hand, evidence is limited on the labor market supply response during the fracking boom. Several studies show that employment and population increased over the course of the fracking energy boom (Weber 2012, Weber 2014, Brown 2014). However, Ruddel et al. (2014) and White (2012) highlight to the transient nature of many extraction workers. The authors refer to them as drive-in and drive-out or fly-in and fly-out employees that live in temporary housing or "man camps" when working. The unavailability of pertinent migration data and the transient nature of many workers make estimating the in-migration response to the labor demand shock challenging.

Economic theory suggests that during the resource extraction boom total wages will be bid up. However, in the fracking boom landowners benefit through leasing their mineral rights to the extraction companies. The royalty payments received, often by local residents, can be lump sum, persist over the course of the

\footnotetext{
${ }^{6}$ Wages being bid up in the non-extraction traded sector over time can result in contraction in the traded sectors (manufacturing, construction, etc.).
} 
production period, among other possibilities (Weidner et al., 2009). Thus, there is an income shock to a community due to extraction that is separate from the labor market shock.

\section{B. Theoretical Connections Between Resource Booms and Crime}

The economic theory of crime is largely attributed to the work of Gary Becker (1968). Becker's rational choice theory posits that economic agents weigh costs and benefits in deciding whether to engage in criminal activity or not. For example, this literature highlights benefits from criminal activity in areas with income shocks and high economic inequality. Alternatively, the costs to committing a crime would include the probability of apprehension and imprisonment and the opportunity cost legitimate employment, among other costs. Deller and Deller (2010) include Becker's rational choice model along with theories from criminology and sociology to examine crime in rural communities. Following Grinols and Mustard (2006) I draw upon relevant theories to examine several of the competing theoretical predictions of a resource boom on local crime.

\section{Reductions in crime}

Wage and income effect: Economic theory predicts an increase in wages for low-skilled extraction workers and other related industries. Furthermore, if the local labor supply is not perfectly elastic non-traded local wages would also be expected to rise. The natural gas fracking boom also creates an increase in local incomes due royalty payments to landholders. Thus, the higher wages and incomes increase the opportunity cost of apprehension, which economic theory predicts to lower crime rates. Gould et al. (2002) find that increased wages and employment for low-skilled workers reduced crime. 
Development effect: Increased fracking activity can encourage local economic development in related industries. For example, Allcott and Keniston (2014) find that manufacturing can actually grow in resource boom communities as firms supply inputs to the extraction sector. The development channel also suggests reduced crime from beneficial labor market spillovers to the non-traded sector.

Increases in crime

Development effect: The fracking related economic development channel could also increase criminal activity. First, disamenities associated with fracking, such as pollution and heavy truck traffic, may discourage new firms and residents from locating in a community. Second, some service industries such bars, prostitution, drugs, etc. may be drawn to boomtowns. These industries service extraction workers, and can become congregation points for criminal activity.

Increased payoff to crime: Rational choice theory suggests that as wages and income in a community increase so does the benefits to committing a crime. The increased payoff to crime would be exacerbated if gains from the fracking boom were unequally distributed. For instance, extraction workers and large landowners may disproportionately benefit from the fracking boom compared to low-skilled residents. Economic literature has suggested that having lower-income people near high-income people provides a rational incentive to commit crime (Deller and Deller 2010). Furthermore, anomie or strain theory notes that inequality can create an envy effect and impact violent crimes (Kelly 2000).

Probability of apprehension: The increase in population and economic activity can put a strain on the local infrastructure. Kowalski and Zajac (2012) note that phone calls to police increased by over 33\% in Pennsylvania energy producing counties between 2006 and 2010. With law enforcement stretched thin and local governments unable to quickly adjust to the rapidly changing environment it is likely that the threat of arrest and prosecution has declined 
in boomtowns.

Fracking induced population changes: The population growth from resource booms comes primarily from young, male extraction workers and support industries (Ruddell et al. 2014). These demographic changes create an imbalance in the population sex-ratio, and encourage specific types of crimes, in this case potentially crimes against women. While population growth alone can fuel crime, an influx of young males can further perpetuate the problem. In particular, young males participate in a disproportionate amount of violent and property crimes. Furthermore, Deller and Deller (2010) note that when the newcomers enter a community social capital deteriorates and crime tends to increase.

The theories described above suggest that there are competing effects that could result in an increase or decrease in overall crime rates. However, it is also possible that these mechanisms could cause different impacts across types of crimes. In particular, one would expect that the income and beneficial development effects would primarily affect property crimes. Thus, for property crimes to increase the increased payoff to crimes would have to out weigh the opportunity cost of getting caught. This could be the case if the benefits from the fracking boom are disproportionately concentrated among extraction workers and landowners, while local residents do not benefit or are economically worse off. This scenario seems unlikely, especially during the boom phase. Thus, I expect property crimes to not differ between boom and non-boom counties.

The wage and income as well as development effects would also be expected to influence violent crimes. In the same channel as property crimes, being apprehended for committing a violent crime would affect ones earning potential, likely decreasing violent crimes. Conversely, extraction workers often earn high wages in remote areas. The development effect from industries servicing workers may perpetuate violent crimes. For example, bars and strip clubs may serve as gathering places, leading to alcohol-induced crimes. While the sex ratio 
imbalance may lead to a higher incident of conflicts with local residents and increase sexual assaults. Consequently, I expect an increase in aggravated and sexual assaults in boomtowns.

\section{Data and Sample Description}

To examine the effect of activities related to the natural gas boom on local crime I use county level data from New York and Pennsylvania. Data on crime are from the Federal Bureau of Investigation's (FBI) Uniform Crime Report for seven FBI Index I offenses ${ }^{7}$. The offenses include violent crime (aggravated assault, rape, robbery, and murder) as well as property crimes (larceny, burglary, and auto theft). I obtained data on the number of unconventional natural gas wells drilled by county from the Pennsylvania Department of Environmental Protection. I use the U.S. Census Bureau's demographic data on gender, race and age groups to calculate their share in each county and the population density. The employment and unemployment data comes from the Bureau of Labor Statistic's Local Area Unemployment Statistics data. Finally, I use county-level income data from Bureau of Economic Analysis Local Area Personal Income (BEA LAPI) database. The BEA revised their income statistics to include royalty income from mineral extraction ${ }^{8}$, among other sources of income. Thus, the income data provide a more accurate portrayal of the income shock in a community from fracking than wages or salary data.

\footnotetext{
${ }^{7}$ For more information see: http://www.fbi.gov/about-us/cjis/ucr/ucr

${ }^{8}$ For more information on the BEA's Local Area Personal Income revision and methodology see:www.bea.gov/scb/pdf/2013/12\%20December/1213 lapi-text.pdfand www.bea.gov/regional/pdf/lapi2011.pdf
} 


\section{A. Sample Selection}

The initial sample includes counties in Pennsylvania and New York from 2004 through 2012. The states were chosen because they both share the Marcellus shale region, yet differ in natural gas extraction policy. New York implemented a moratorium on fracking, while the Pennsylvania allowed early adoption of fracking technology (Rabe and Borick 2013). Figure 1 shows the Utica and Marcellus shale formations shared by the two states. The differing policies in the region provide a natural experiment to analyze the effect to natural gas production on crime.

The policies in New York and Pennsylvania have led to dramatically different levels of natural gas production. Figure 2 displays the natural gas production in both states from 2004 to 2012. Prior to 2007, natural gas production growth in each state was relatively stagnant. Pennsylvania produced an average of 179 million mcf ${ }^{9}$ and New York averaged 52 million mcf. However, by 2012 the Commonwealth of Pennsylvania's natural gas production increased to 1,298 million mcf, a $625 \%$ increase. In contrast, New York's natural gas production remained flat over the sample time frame. The increased production is largely attributed to the adoption of fracking technology used in the Marcellus Shale. Furthermore, the production of natural gas closely matches unconventional natural gas wells, which produce natural gas from shale formations, drilled in Pennsylvania. Thus, the sample is restricted to only include counties that have some coverage in the Marcellus shale region shown in Figure 1. This provides an objective measure of their extractive potential in the natural experiment research design.

${ }^{9}$ mcf stands for 1,000 s of cubic feet. 


\section{B. Unconventional Well Data and Determining Boom Counties}

I obtained county level data on unconventional natural gas wells from the Pennsylvania Department of Environmental Protection. The well data comprises bore holes drilled in unconventional shale formation, which typically t produce natural gas using hydraulic fracturing techniques. I focus on the number of wells being drilled, rather than production amounts for several reasons. First, natural gas production data can be highly variable from year to year due to measurement and reporting challenges. Thus, the most convincing studies using production data look at longer-run effects, for example over a decade (Weber 2014, Brown 2014). Second, economic activity associated with drilling, such as increases in labor, are often associated with boomtowns. Jaquette (2009) suggests that the majority of the extraction related jobs come from well development and construction, while relatively few workers are involved in production and reclamation. Third, natural gas production often continues years, or even decades, after the well is initially drilled. Thus, production data can be a misleading measure of economic activity related to the fracking boom.

I use the number of unconventional wells to determine the counties that experience an unanticipated labor demand shock from fracking. Figure 3 displays the distribution of new unconventional wells drilled conditional on a county having at least one well over the sample period. Over $80 \%$ of county-years have under 75 new unconventional wells drilled. This comes both from counties with few total wells, as well as the initial 'test' drilling period for boom counties. I define a boom county as a county with over 75 new unconventional wells in a year. This allows for both temporal and geographic variation in the fracking boom. Boom counties are grouped together in the southwest corner of Pennsylvania and in northern the northern portion of the Commonwealth near the New York border. 
Using a boom county indicator, rather than the number of wells drilled, is a subjective measure of fracking activity. Nonetheless, it is consistent with the literature on local impacts of resource booms (Black et al. 2005, Weber 2012, Jacobsen and Parker 2014). I also show in section 5.2 that the general results are

robust to different measures of the boom county along with using the number of unconventional wells as a continuous variable.

Table 1 displays descriptive statistics for boom and non-boom counties in the Marcellus region from 2004 through 2012. The boom county sample includes 63 county-years while the non-boom region comprises 873 county-years. The pvalue in Table 1 tests for difference in the means of boom and non-boom counties, where the null hypothesis is that they are not different. Boom counties had on average 64.7 unconventional wells compared to 1.6 for non-boom counties. The boom and non-boom counties had similar demographic profiles during the sample period. Boom and non-boom counties had age, population density, unemployment, employment, population and income difference in means that were not statistically different from zero at the $1 \%$ level. The employment change in boom counties was statistically different than non-boom counties at the $1 \%$ level, while population growth was statistically insignificant. This is consistent with local job creation associated with fracking, but disamenities from drilling reducing population growth relative to non-boom counties.

\section{Empirical Methods and Estimation}

My empirical strategy uses annual panel data from 2004-2012 to estimate the effect of unconventional natural gas wells on crime. The empirical model uses variation in both the timing of fracking in a county and the moratorium on fracking natural gas in the State of New York over the sample time frame. Thus, I exploit the natural experiment in the Marcellus shale region. Counties in 
Pennsylvania can receive the "treatment" of hight fracking activity, while similar counties in New York can only be "controls" due to the policy. The base model specification uses all counties in the Marcellus shale region. I experiment later with alternative samples, specifications and estimation techniques and the results prove robust. The basic analysis begins with the following regression model:

$$
Y_{c t}=\beta_{1} \text { HighFracking }_{c t}+\beta_{2} \text { LowFracking }_{c t}+X_{c t} \Theta+\alpha_{c}+\gamma_{t}+\varepsilon_{c t}
$$

where $Y_{c t}$ is a measure crime in county $\mathrm{c}$ at time t. Crime is the inverse hyperbolic sine transformed number of reported crimes per 100,000 residents. The inverse hyperbolic sine transformation ${ }^{10}$ allows for the same interpretation as a $\log$ transformation ${ }^{11}$ (Burbidge, et al. 1988). However, it is defined at zero, and thus, does not drop county-years with zero crimes. The variable HighFracking ${ }_{c t}$ is a indicator variable equal to 1 if county $c$ year $t$ had over 75 unconventional natural gas wells and 0 otherwise. Similarly, LowFracking $c$ is an indicator variable equal to 1 if county $c$ year $t$ has between 1 and 75 unconventional wells and 0 otherwise. The estimated parameters $\beta_{1}$ and $\beta_{2}$ can then be interpreted as the percent change in crime attributable to high and low fracking activity in a county respectively.

The vector $X_{c t}$ contains a wide range of demographic and labor market control variables listed in Table 1. By using panel data I am able to control for several types of unobserved heterogeneity. $\alpha_{c}$ is a county fixed effect that controls for observable and unobservable differences across counties that are constant over time. The time fixed effect $\gamma_{t}$ controls for common shocks that affect in all

\footnotetext{
${ }^{10}$ The inverse hyperbolic sine transformation is expressed as $\ln \left(r+\sqrt{r^{2}+1}\right)$, where $r$ is the variable to be transformed.

${ }^{11}$ The results are robust to using the $\log$ transformation and adding 1 to each observation i.e. $\log \left(\mathrm{Y}_{\mathrm{ct}}+1\right)$.
} 
counties over time. Furthermore, the inclusion of county and time fixed effects is crucial to proper identification given my research design. Finally, $\varepsilon_{c t}$ is a random disturbance term. To estimate the model in equation 1, I use unweighted ordinary least squares (OLS) regressions. To correct for serial correlation I cluster the standard errors by county following Arellano (1987).

The criminology literature has suggested that crime rates are closely tied to local labor market conditions (Gould et al. 2002, Levitt, 2001). Therefore, I include pertinent labor market variables like the unemployment rate, income per capita along with the employment level and employment growth. Previous studies on the effect of casinos on crime (Grinols and Mustard 2006) and drunk driving (Cotti and Walker 2010) have also highlighted the importance of controlling for population-induced effects. Thus, I add controls for various demographic groups, the level of population and population growth from the U.S. Census. Unfortunately, a weakness in the Census data is its inability to capture the transient nature of the natural gas and oil labor market.

\section{Results}

\section{A. Basic Results}

I begin examining the effect of fracking activity on crime by estimating equation 1. I use a balanced sample, containing high fracking, low fracking and control counties within the Marcellus Shale region for New York and Pennsylvania. Table 2 shows estimates for all violent crimes (murder, rape, robbery and aggravated assault) as well as all property crimes (burglary, larceny, and auto theft). The results in Table 3 decompose crimes into each of the seven FBI Index I offenses. In each case the dependent variable is the hyperbolic sine transformation of crime rates for 100,000 residents. Thus, the estimates can be interpreted as elasticities. The second and fourth columns in Table 2 include the control 
variables listed in Table 1. Finally, the estimates in both Table 2 and Table 3 include county and year fixed effects as well as control variables. F-statistics for the joint significance of the year and county fixed effects are statistically significant in all models.

The results in Table 2 show a positive effect of fracking activity on violent crime. For example, the first column in Table 2 suggests that a high fracking county experiences an increase in violent crimes of approximately $35 \%$, compared to counties without any fracking. Similarly, low fracking counties also experience a positive and statistically significant increase in violent crime of $11 \%$. This relationship also holds when I include a several pertinent control variables common in the crime literature (Levitt 2001, Gould et al. 2002). The results also show that the effect of fracking is smaller for property crimes. Without including control variable (column 3 ), the effect of fracking is a less than $10 \%$ increase on property crimes for high intensity areas. While the effect on property crimes is statistically insignificant at the $10 \%$ level when including control variables.

The results in Table 3 examine each of the FBI Index I offenses individually. Panel A shows violent crimes, while Panel B examines property crimes. In general, Table 3 suggests that the violent crime increase (shown in Table 2) is primarily driven by increases in rape and aggravated assault. Both rapes and aggravated assaults increase by over $30 \%$ in high fracking activity counties. Furthermore, murder and robbery are statistically insignificant at the $10 \%$ level. The r-squared suggests that the model examining variation in murders is under 0.4 , while the model for aggravated assault is 0.77 . Thus, even including fixed effects and control variables the model explains less than $40 \%$ of the variation in murders. Finally, the high fracking variable is statistically insignificant for all three types of property crimes at the $10 \%$ level. 


\section{B. Falsification Tests}

The natural experiment provides an arguably exogenous variation in policy regimes between fracking counties in Pennsylvania and non-fracking counties in New York. Furthermore, the difference-in-differences strategy, shown in equation 1, also hinges on the pre-existing trends between fracking and non-fracking areas not differing. If for example, fracking boom counties were experiencing faster growth in criminal activity relative to non-fracking counties in the Marcellus region, this could lead to estimating a positive spurious relationship.

I examine whether the positive association between the fracking boom and crime discussed in section 5.1 is due to differential pre-exisiting trends by estimating falsification tests. I do this by estimating equation (1) with the fracking boom indicator variables shifted 3 or 4 years ahead of the actual boom. Thus, conditioning on time and county fixed effects, contemporaneous fracking indicators should predict a crime and fracking relationship, if there is one, while leads prior to the boom should not. Table 4 shows the results of the falsification tests. Each model includes all of the control variables as well as county and time fixed effects. The high and low fracking indicator variables are not statistically significant at the $10 \%$ level for property and violent crimes. Thus, the falsification tests do not provide evidence of a spurious, positive result due to pre-exisiting trends.

\section{Robustness Checks}

While I believe that my identification strategy, functional form choices, etc. are reasonable, nonetheless, I recognize that thoughtful researchers could choose alternative approaches. Thus, I show several alternative estimates in Table 5 to show that my results are robust to alternative strategies. I focus on evaluating total violent and property crimes. Each set of results use county and year fixed effects 
and the full range of control variables. The comparable basic results can be found in Table 2. The basic results suggest a 30\% increase in violent crimes and no statistically significant effect in property crimes.

The first set of robustness checks considers alternative specifications for both the dependent and independent variable of interest. Model 1 displays estimate where the dependent variable is the level of crime, instead of the inverse hyperbolic sine transformation of the crime rate. Using the level of crime rate suggests that high fracking activity increases violent crimes by 61 per 100,000 residents. While similar to the basic model, high fracking activity has a statistically insignificant effect on property crime rates. Next, I interact the high fracking and low fracking activity dummy variables with the demeaned county population. This strategy was used by Cotti and Walker (2010) to test for population induced impacts on drunk driving from casino openings. The coefficient can be interpreted as the percent increase in crime rate from high (or low) fracking activity in a county with average population, relative to the control group of counties without any fracking taking place. The results on the high and low fracking variables in model 2 are similar to the basic model results. Further, the interaction terms show a statistically insignificant population induced effect from fracking activity. Finally, models $3-5$ use alternative indicators of the fracking boom. Model 3 uses the number of unconventional wells similar to the specification employed by Paredes et al. (2015). It suggests that every additional unconventional well is associated with a $0.1 \%$ increase in violent crimes. The other boom county indicators in models 4 and 5 show an approximately $22 \%$ increase in violent crimes from fracking.

Next, I examine an alternative sample of counties. Paredes et al. (2015) argues that parts of New York still experience economic activity associated with fracking despite its moratorium on the practice. For example, a major railroad line travels along the Pennsylvania and New York border and several extraction companies 
have located regional headquarters on the New York side of the border. In the treatment and control paradigm, this would suggest that counties in Upstate New York should also be considered treated counties. I would expect this to downward bias my results reported in Table 2. Model 6 shows results eliminating the New York border counties. The high fracking indicator variable remains statistically significant at the $1 \%$ level and high fracking activity is associated with a $33 \%$ increase in violent crimes.

The final set of robustness checks examines alternative estimation techniques. The basic results from section 5.1 use unweighted OLS regressions with standard errors cluster by county. It could be argued that since crime rates are highly variable, and individual crimes are aggregated to the county that it could be appropriate to use weighted least squares. However, Solon et al. (2013) suggest using caution and relying on diagnostics when using weighted estimation to correct for heteoskedasticity or identify average partial effects in the presence of unmodeled heterogeneity. Model 7 displays results for weighting equation 1 by county-year population. The estimated coefficients imply that high fracking activity causes a $20 \%$ increase in violent crimes compared to the control group, while low fracking increases violent crimes by $5 \%$. The estimates weighting by county-year population are smaller than the unweighted results, yet still statistically significant for violent crimes. The fixed effects Poisson estimation technique is another potential estimation strategy that accounts for the countnature of the crime data. The fixed effects Poisson estimation in Model 8 yields similar results as the base models.

\section{Estimates of Victimization Costs of Fracking}

Policy makers and natural gas proponents often cite the benefits in terms of jobs and income that are created in a community. However, the welfare costs of 
victims of crimes, among other costs, should also be considered to make optimal policy decisions. The results presented in section 5 suggest that the fracking boom in the Marcellus region attributed to an increase in violent crimes, while property crimes remained unchanged. I use published estimates of the victimization costs for FBI Index I crimes to infer an aggregate community level crime cost to fracking activity.

Table 6 presents victimization costs from McCollister et al. (2010). The costs for each criminal category include measures of tangible costs (e.g. medical expenses, property damage, etc.) and intangible costs (e.g. elevated fear, pain and suffering, etc.). McCollister et al. (2010) provide a comprehensive methodology to estimating the cost of crimes to society and use the most current available data different crimes in 2008 dollars. The estimated victimization costs range from almost $\$ 9$ million for murder to just over $\$ 3,500$ for larceny.

My estimates suggest that violent crimes increased in a county by approximately $35 \%$ from fracking, while property crimes were statistically insignificant at the $10 \%$ level. On average, the violent crime increase in boom counties was 61 per 100,000 residents. The violent crime increase is primarily attributed to increases in aggravated assaults (40 per 100,000 residents) and sexual assaults (20 per 100,000 residents). I focus on these two crime metrics because of their statistical significance in the results, and to provide a lower bound for the aggregate county level victimization. The summary statistics in table show that the average population in boom counties was approximately 100,000 residents over the sample timeframe. Thus, the estimates can be thought of the amount of additional crimes in the average county per year. Using the estimated victimization costs in table 6 suggests that the county cost of aggravated 
assaults is approximates $\$ 4.8$ million and sexual assaults is $\$ 4.2$ million per year $^{12}$.

\section{Conclusion}

In the 2000s the U.S. experienced a boom in natural gas production from the advent of fracking technology. The localized effects of extraction have been concentrated in areas with shale plays. I examine one negative consequence of resource extraction in the Marcellus shale region, increased crime. To estimate the effect of the fracking boom on crime I exploit a natural experiment in policy regimes between Pennsylvania and New York and use panel data estimation techniques. The results show that areas experiencing a natural gas extraction boom suffer increase in overall violent crimes, while property crimes remain similar to non-boom areas. I examine FBI Index I offenses and show that the increase in violent crimes appears to be driven by increases in aggravated assaults and rapes. Victimization costs from the criminology literature suggest that fracking is associated with a cost of $\$ 9$ million per boom county each year.

I show that the results are robust to a wide array of control variables that include demographic categories, population density, and labor market variables. In particular, I include population growth and employment growth variables to control for changes in the size of the population, which has been linked to crime rates in previous studies. I also show that the results are robust to alternative specifications of the dependent variable and explanatory variable of interest, an indicator for a county experiencing a resource extraction shock. Furthermore, I show my estimates are robust to alternative samples (eliminating New York border counties) and estimation methods, such as weighting techniques and fixed

\footnotetext{
${ }^{12}$ E.g. 40 additional aggravated assaults per year $* \$ 240,776$ victimization costs $=\$ 9,631,040$ per boom county per year.
} 
effects Poisson model. Nonetheless, one should take caution in extrapolating these results to other parts of the country experiencing the energy boom.

I provide several theoretical explanations from economics, crime and sociology for changes in local crime rates. Unfortunately, pertinent data on short-term labor migration of extraction workers is either unreliable or not available. One interpretation of the results suggests that the influx of temporary extraction workers creates a magnate for criminality. Thus, regions can experience a negative consequence of the so-called 'resource curse' during the natural resource boom. The results eliminating New York border counties suggest that crime is not just being relocated within the region. The results suggest that policy makers should include increased crime as a potential cost to unconventional natural gas extraction and make appropriate investments in public services, such as public safety. 


\section{REFERENCES}

Allcott, Hunt and Daniel Keniston. 2014. "Dutch Disease or Agglomeration? The Local Economic Effects of Natural Resource Booms in Modern America." NBER Working Paper No. 20508.

Archbold, Carol A. 2013. "Policing the Patch": An Examination of the Impact of the Oil Boom on Small Town Policing and Crime in Western North Dakota." North Dakota State University: Fargo, ND: North Dakota State University.

Arellano, Manuel. 1987. "Computing Robust Standard Errors for Within-Groups Estimators." Oxford Bulletin of Economic Statistics, 49, 431-434.

Becker, Gary. 1968. “Crime and punishment: An economic approach.” Journal of Political Economy, 76:169-217.

Black, Dan., Terra McKinnsh, and Seth Sanders. 2005a. "The economic impact of the coal boom and bust." Economic Journal, 115, 449-476.

Black, Dan., Terra McKinnsh, and Seth Sanders. 2005b. "Tight Labor Markets and the Demand for Education: Evidence from the Coal Boom and Bust" Industrial and Labor Relations Review, 59(1), 3-16.

Brown, Jason P. 2014. "Production of Natural Gas From Shale in Local Economies: A Resource Blessing or Curse?” Economic Review, 99(1) 5-33.

Burbidge, John B., Lonnie Magee and A. Leslie Robb. 1988. "Alternative Transformations to Handle Extreme Values of the Dependent Variable." Journal of the American Statistical Association, 83, 123-127.

Carrington, Kerry and Margaret Pereira. 2011. "Assessing the Social Impacts of the Resources Boom on Rural Communities." Rural Society, 21:2-20.

Corden, W. Max and Peter J. Neary. 1982. "Booming Sector and DeIndustrialisation in a Small Open Economy." Economic Journal, 92, 825-848.

Cotti, Chad D., and Douglas M. Walker. 2010. "The impact of casinos on fatal alcohol-related traffic accidents in the United States." Journal of Health Economics 29. 788-796.

Deller, Steven C. and Melissa A. Deller. 2010. "Rural Crime and Social Capital" 
Growth and Change, 41(2) 221-275.

Dobbs, Edwin. 2013. "The New Oil Landscape." National Geographic. March Accessed at: http://ngm.nationalgeographic.com/2013/03/bakken-shaleoil/dobb-text

Eligon, John. 2013. "An Oil Town Where Men Are Many, and Women Are Hounded" New York Times. January 15.

http://www.nytimes.com/2013/01/16/us/16women.html?pagewanted=all\&_r=0

Food and Water Watch. 2013. "The Social Cost of Fracking." Accessed at http://www.foodandwaterwatch.org/reports/the-social-costs-of-fracking/

Fitzgerald, Timothy. 2013. "Frackonomics: Some Economics of Hydraulic Fracturing." Case Western Reserve Law Review, 63(4) 1337-1361.

Gould, Eric D., Bruce A. Weinberg and David B. Mustard. 2002. "Crime Rates and Local Labor Market Opportunities in the United States: 1977-1997." The Review of Economics and Statistics, 84(1), 45-61.

Grinols, Earl L., and David B. Mustard. 2006. "Casinos, Crime, and Community Costs." The Review of Economics and Statistics, 88(1) 28-45.

Haggerty, Julia, Patricia H. Guide, Mark Delorey, Ray Rasker, 2014. "Long-term effects of income specialization in oil and gas extraction: The U.S. West, 19802011." Energy Economics, 45. 186-195.

Horwitz, Shari. 2014 "Dark side of the boom" Washington Post, Sept. 28

http://www.washingtonpost.com/sf/national/2014/09/28/dark-side-of-the-boom/

Jacobsen, Grant D. and Dominic P. Parker 2014. "The Economic Aftermath of Resource Booms: Evidence from Boomtowns in the American West." Economic Journal, in press

Jacquet, Jeffrey. 2009. "Energy Boomtowns and Natural Gas: Implications for Marcellus Shale Local Governments and Rural Communities." NERCRD Rural Development Paper No. 43

Kelly, Morgan. 2000. "Inequality and crime." Review of Economics and Statistics 82: 530-539. 
Kowalski, Lindsay and Gary Zajac. 2012. "A Preliminary Examination of Marcellus Shale Drilling Activity and Crime Trends in Pennsylvania." University Park, PA: Justice Center for Research.

Levitt, Steven. 2001. "Alternative Strategies for Identifying the Link Between Unemployment and Crime.” Journal of Quantitative Criminology, 17(4), 377.

Luthra, Asha D., William B. Bankston, DeAnn M. Kalich, and Craig J. Forsyth. 2007. "Economic Fluctuation and Crime: A Time Series Analysis of the Effects of Oil Development in the Coastal Regions of Louisiana." Deviant Behavior 28:113-130.

McCollister, Kathryn E., Michael T. French, and Hai. Fang. 2010. "The cost of crime to society: New crime-specific estimates for policy and program evaluation." Drug and Alcohol Dependence, 108, pg 89-109.

Paredes, Dusan, Timothy Komarek, Scott Loveridge. 2015. "Income and Employment Effects of Shale Gas Extraction Windfalls: Evidence from the Marcellus Region.” Energy Economics, 47, pg 112-120.

Rabe, Barry G. and Christopher Borick. 2013. "Conventional Politics for Unconventional Drilling? Lessons from Pennsylvania's Early Move into Fracking Policy Development." Review of Policy Research, 30(3), 321-340.

Ruddell, Rick. 2011. "Boomtown Policing: Responding to the Dark Side of Resource Development.” Policing, 5:328-342.

Ruddell, Rick, Natalie R. Ortiz, and Matthew O. Thomas. 2013. Boomtown Blues: Economic Development, Crime and Decreased Quality of Life. Paper presented at the Annual Meeting of the American Society of Criminology, November, Atlanta, GA.

Ruddell, Rick, Dheeshana S. Jayasundara, Roni Mayzer, and Thomasine Heitkamp. 2014. "Drilling Down: An Examination of the Boom-Crime Relationship in Resource Based Boom Counties." Western Criminology Review, 15(1):3-17

Sachs, Jeffrey D., and Andrew M. Warner. 2001. "The curse of natural resources." European Economic Review, 45, 827-838.

Shepard, Susan E. 2013. “Wildcatting: A Stripper’s Guide to the Modern 
American Boomtown" Buzzfeed.com, July 16

http://www.buzzfeed.com/susanelizabethshepard/wildcatting-a-strippers-guide-tothe-modern-american-boomtow

Solon, Gary, Steven J. Haider, and Jeffrey M. Wooldridge. 2013. "What are we weighting for?” NBER Working Paper No. 18859

van der Ploeg, Frederick. 2011. "Natural Resources: Curse or Blessing?” Journal of Economic Literature, 49(2): 366-420.

Weber, Jeremy G. 2014. “A Decade of Natural Gas Development: Making of a resource curse?" Resource and Energy Economics 37, 168-183.

Weber, Jeremy G. 2012. "The effect of a natural gas boom on employment and income in Colorado, Texas and Wyoming." Energy Economics, 34, 1580 1588 .

Weidner, Krista, Cathy Faulcon Bowen, Michael Jocobson, and Ross Pifer. 2009. "Natural gas exploration: A Landowner's guide to financial management." University Park: PennState Cooperative Extension. http://pubs.cas.psu.edu/FreePubs/pdfs/ui394.pdf

White, Nancy E. 2012. "A Tale of Two Shale Plays." The Review of Regional Studies 42:107-119. 
Figure 1: Shale Formations in the Northeastern United States

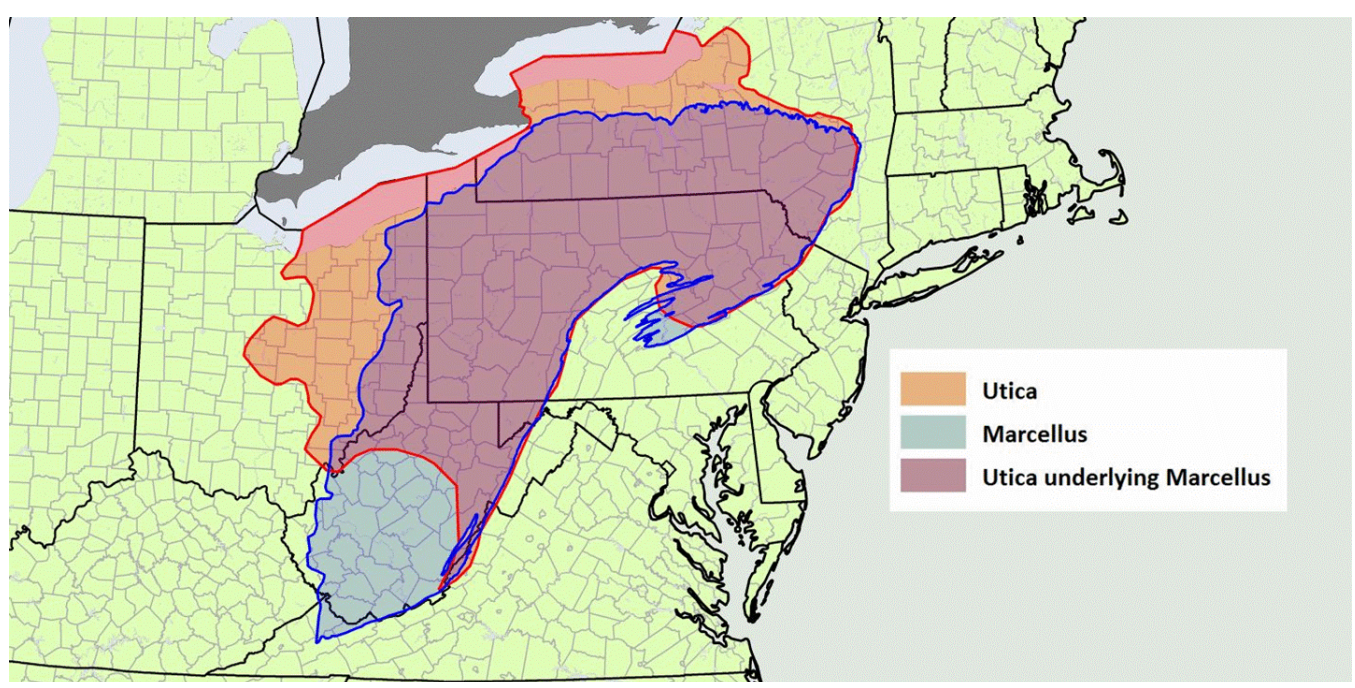

Source: Energy Information Administration 
Figure 2: Natural Gas Production By State

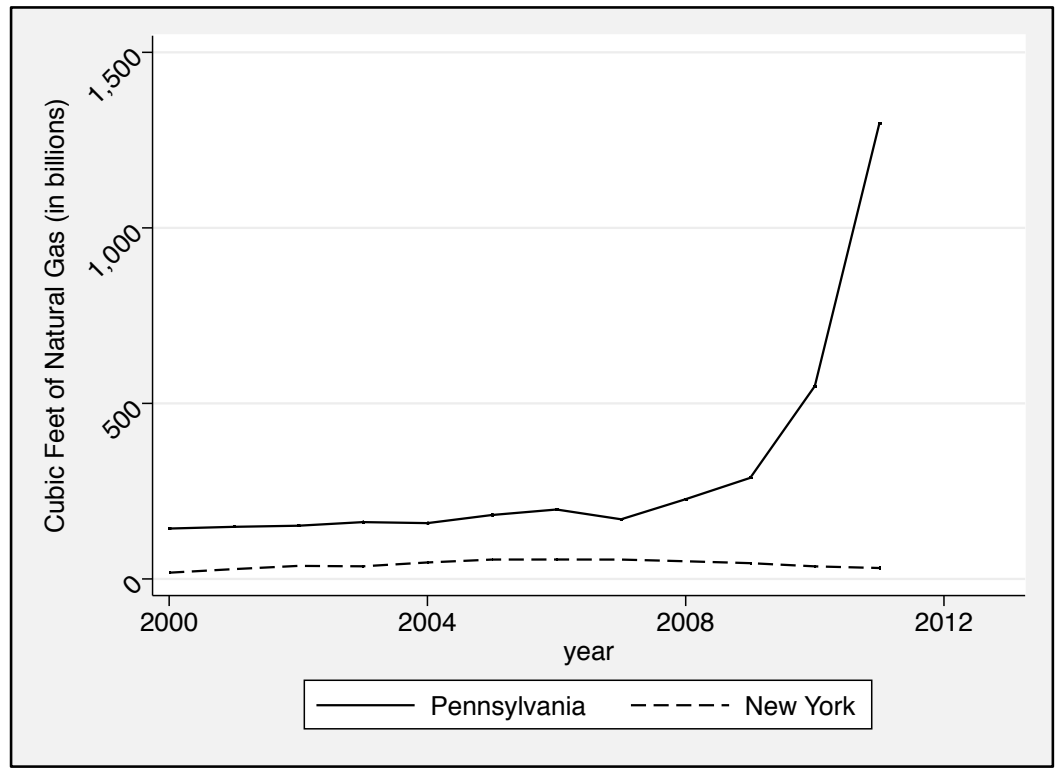

Source: Author's calculation from ERS County-level Oil and Gas Production in the U.S.

Figure 3: Distribution of Unconventional Natural Gas Wells

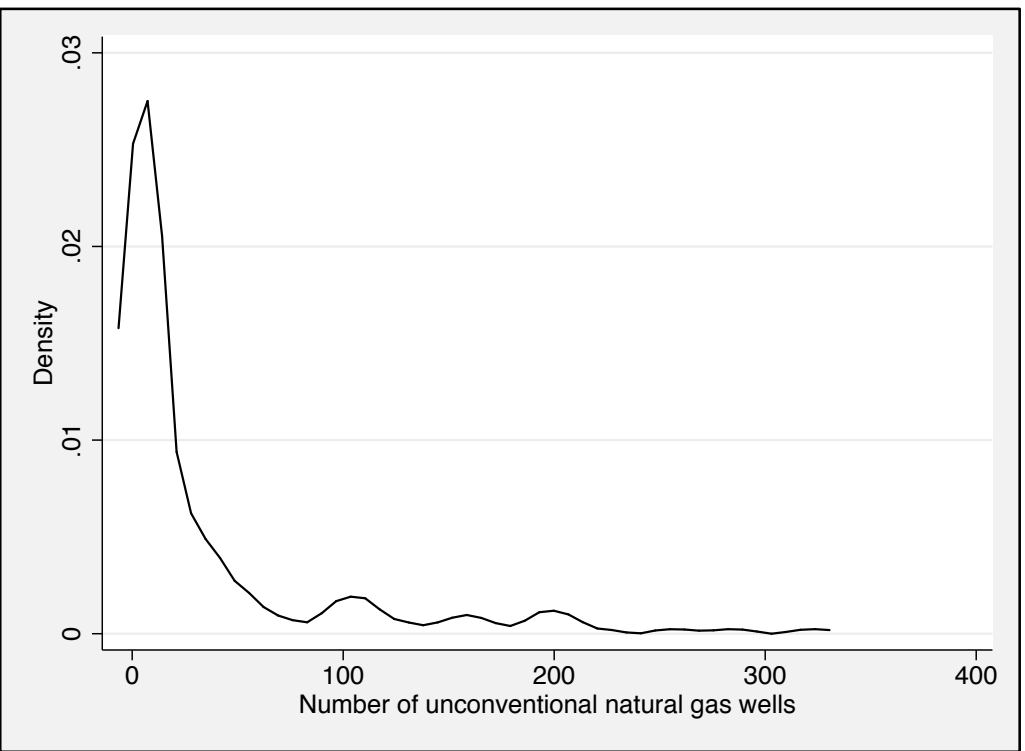

Source: Author's calculation from Pennsylvania Department of Environmental Protection 
TABle 1: SUMMARY STATISTICS COMPARING BOOM AND NON-BOOM COUNTIES (2004-2012)

\begin{tabular}{|c|c|c|c|c|c|}
\hline & \multicolumn{2}{|c|}{ Boom Counties } & \multicolumn{2}{|c|}{ Non-Boom Counties } & \multirow[b]{2}{*}{ P-value } \\
\hline & Mean & Std. Dev. & Mean & Std. Dev. & \\
\hline \multicolumn{6}{|l|}{ Dependent Variables } \\
\hline Violent Crime Rate & 146.1 & 50.1 & 216.5 & 110.5 & 0.000 \\
\hline Property Crime Rate & $1,566.6$ & 399.5 & $1,914.4$ & 575.0 & 0.000 \\
\hline Auto Theft Rate & 81.2 & 32.6 & 81.6 & 59.6 & 0.959 \\
\hline Larceny Rate & $1,112.40$ & 340.2 & $1,395.8$ & 457.4 & 0.000 \\
\hline Burglary Rate & 372.9 & 100.9 & 437 & 171.6 & 0.004 \\
\hline Aggravated Assault Rate & 91.0 & 38.7 & 145 & 75.7 & 0.000 \\
\hline Robbery Rate & 27.5 & 20.8 & 42.2 & 48.1 & 0.017 \\
\hline Rape Rate & 25.4 & 13.3 & 27.2 & 30.6 & 0.660 \\
\hline Murder Rate & 2.1 & 2.2 & 2.2 & 2.4 & 0.629 \\
\hline \multicolumn{6}{|l|}{ Control Variables } \\
\hline Unconventional Wells & 64.7 & 82.8 & 1.4 & 6.2 & 0.000 \\
\hline$\%$ Male & 0.495 & 0.010 & 0.497 & 0.021 & 0.415 \\
\hline$\%$ White & 0.963 & 0.018 & 0.93 & 0.053 & 0.000 \\
\hline$\%$ Black & 0.02 & 0.016 & 0.042 & 0.04 & 0.000 \\
\hline$\%$ Age $0-9$ & 0.111 & 0.006 & 0.112 & 0.013 & 0.779 \\
\hline$\%$ Age $10-19$ & 0.135 & 0.007 & 0.139 & 0.013 & 0.029 \\
\hline$\%$ Age $20-29$ & 0.114 & 0.014 & 0.123 & 0.028 & 0.021 \\
\hline$\%$ Age $30-39$ & 0.114 & 0.01 & 0.116 & 0.011 & 0.274 \\
\hline$\%$ Age $40-49$ & 0.149 & 0.01 & 0.148 & 0.012 & 0.602 \\
\hline Population Density & 110.6 & 81.0 & 222.0 & 283.0 & 0.002 \\
\hline Unemployment Rate & 0.167 & 0.192 & 0.167 & 0.183 & 0.995 \\
\hline $\begin{array}{l}\text { Income per capita } \\
(\$ 1,000 \mathrm{~s})\end{array}$ & 27.0 & 4.3 & 27.4 & 4.2 & 0.510 \\
\hline Employment & $47,949.8$ & $32,774.5$ & $72,485.7$ & $96,261.8$ & 0.044 \\
\hline \% Change in Employment & 0.012 & 0.025 & -0.001 & 0.022 & 0.000 \\
\hline Population & $98,919.5$ & $66,217.4$ & $152,808.3$ & $197,394.9$ & 0.031 \\
\hline$\%$ Change in Population & 0.001 & 0.005 & 0.001 & 0.009 & 0.649 \\
\hline
\end{tabular}


TABLE 2: THE EFFECT OF FRACKING ON VIOLENT AND PROPERTY CRIME (2004-2012)

\begin{tabular}{ccccc}
\hline \hline & $(1)$ & $(2)$ & $\begin{array}{c}(3) \\
\text { Property } \\
\text { Crime }\end{array}$ & $\begin{array}{c}\text { (4) } \\
\text { Property } \\
\text { Crime }\end{array}$ \\
VARIABLES & Violent Crime & Violent Crime & & \\
High Fracking & & & & \\
& $0.349^{* * *}$ & $0.351^{* * *}$ & $0.0948^{*}$ & 0.0813 \\
Low Fracking & $(0.0817)$ & $(0.0921)$ & $(0.0551)$ & $(0.0581)$ \\
& $0.115^{* *}$ & $0.109 * *$ & -0.0171 & -0.0135 \\
& $(0.0503)$ & $(0.0534)$ & $(0.0255)$ & $(0.0269)$ \\
Controls & & & & Yes \\
Year FE & No & Yes & No & Yes \\
County FE & Yes & Yes & Yes & Yes \\
Observations & Yes & Yes & Yes & 936 \\
R-squared & 936 & 936 & 936 & 0.854 \\
\hline Notes: Robust standard errors in parenthes $* * * \mathrm{p}<0.01, * * \mathrm{p}<0.05, * \mathrm{p}<0.1$ & 0.847 &
\end{tabular}

Notes: Robust standard errors in parentheses $* * * \mathrm{p}<0.01, * * \mathrm{p}<0.05, * \mathrm{p}<0.1$

Dependent variable is the inverse hyperbolic sine transformation of the number of crimes per 100,000 residents 
TABLE 3: THE EFFECT OF FRACKING ON FBI INDEX I OFFENSES (2004-2012)

\begin{tabular}{|c|c|c|c|c|}
\hline Panel A: Violent Crimes & Murder & Rape & Robbery & $\begin{array}{c}\text { Aggravated } \\
\text { Assault }\end{array}$ \\
\hline \multirow[t]{2}{*}{ High Fracking } & -0.0719 & $0.323 * *$ & -0.249 & $0.344 * * *$ \\
\hline & $(0.282)$ & $(0.161)$ & $(0.269)$ & $(0.128)$ \\
\hline \multirow[t]{2}{*}{ Low Fracking } & $-0.242 *$ & -0.0278 & -0.142 & $0.128 * *$ \\
\hline & $(0.128)$ & $(0.128)$ & $(0.117)$ & $(0.0644)$ \\
\hline Controls & Yes & Yes & Yes & Yes \\
\hline Year FE & Yes & Yes & Yes & Yes \\
\hline County FE & Yes & Yes & Yes & Yes \\
\hline Observations & 936 & 936 & 936 & 936 \\
\hline R-squared & 0.396 & 0.404 & 0.805 & 0.775 \\
\hline Panel B: Property Crimes & Burglary & Larceny & Auto Theft & \\
\hline \multirow[t]{2}{*}{ High Fracking } & 0.0875 & 0.0809 & -0.192 & \\
\hline & $(0.0921)$ & $(0.0635)$ & $(0.194)$ & \\
\hline \multirow[t]{2}{*}{ Low Fracking } & -0.0296 & -0.00776 & $-0.187^{*}$ & \\
\hline & $(0.0284)$ & $(0.0319)$ & $(0.103)$ & \\
\hline Controls & Yes & Yes & Yes & \\
\hline Year FE & Yes & Yes & Yes & \\
\hline County FE & Yes & Yes & Yes & \\
\hline Observations & 936 & 936 & 936 & \\
\hline R-squared & 0.790 & 0.869 & 0.791 & \\
\hline
\end{tabular}

Notes: Robust standard errors in parentheses $* * * \mathrm{p}<0.01,{ }^{* *} \mathrm{p}<0.05,{ }^{*} \mathrm{p}<0.1$

Dependent variable is the inverse hyperbolic sine transformation of the number of crimes per 100,000 residents 
TABLE 4: FALSIFICATION TESTS OF FRACKING BOOM ON VIOLENT AND PROPERTY CRIME

\begin{tabular}{ccccc} 
Analysis Type & \multicolumn{4}{c}{ Fracking Boom Date Falsification Test } \\
\# of Years Boom Date Shifted & 3 years ahead & 4 years ahead & 3 years ahead & 4 years ahead \\
\cline { 2 - 5 } VARIABLES & $(1)$ & $(2)$ & $(3)$ & $\begin{array}{c}(4) \\
\text { Property } \\
\text { Crime }\end{array}$ \\
High Fracking & Violent Crime & Violent Crime & Crime & \\
& & & & 0.00720 \\
Low Fracking & 0.0623 & -0.0492 & 0.0823 & $(0.0433)$ \\
& $(0.106)$ & $(0.100)$ & $(0.0565)$ & -0.00420 \\
Controls & -0.0507 & -0.0679 & 0.0290 & $(0.0150)$ \\
Year FE & $(0.0503)$ & $(0.0751)$ & $(0.0246)$ & Yes \\
County FE & & & & Yes \\
Observations & Yes & Yes & Yes & Yes \\
R-squared & Yes & Yes & Yes & 624 \\
& Yes & Yes & 728 & 0.943 \\
\hline
\end{tabular}

Notes: Robust standard errors in parentheses $* * * \mathrm{p}<0.01, * * \mathrm{p}<0.05, * \mathrm{p}<0.1$

Dependent variable is the inverse hyperbolic sine transformation of the number of crimes per 100,000 residents

These results are from the difference-in-difference specification that moves the fracking boom date ahead as a falsification test. 
TABle 5: RoBUstness CHECKS OF BASIC RESUltS

\begin{tabular}{|c|c|c|c|}
\hline Model & Variable & $\begin{array}{l}\text { Violent } \\
\text { Crime }\end{array}$ & $\begin{array}{l}\text { Property } \\
\text { Crime }\end{array}$ \\
\hline $\begin{array}{l}\text { Alternative Specification } \\
\text { 1. Dependent variable in levels } \\
\text { (Crimes per } 100,000 \text { population) }\end{array}$ & High Fracking & $\begin{array}{l}61.04 * * * \\
(19.67)\end{array}$ & $\begin{array}{l}109.9 \\
(89.55)\end{array}$ \\
\hline \multirow{5}{*}{$\begin{array}{l}\text { 2. Fracking indicators interacted with } \\
\text { de-meaned population. For example } \\
\text { High Fracking*Population }=\text { High } \\
\text { Fracking* [Log(population)- } \\
\log (\text { mean population) }]\end{array}$} & Low Fracking & $\begin{array}{l}26.80 * * \\
(13.16)\end{array}$ & $\begin{array}{l}-25.77 \\
(41.77)\end{array}$ \\
\hline & High Fracking & $\begin{array}{l}0.358 * * * \\
(0.0896)\end{array}$ & $\begin{array}{c}0.0778 \\
(0.0622)\end{array}$ \\
\hline & Low Fracking & $\begin{array}{l}0.110 * * \\
(0.0523)\end{array}$ & $\begin{array}{l}-0.0154 \\
(0.0277)\end{array}$ \\
\hline & High Fracking*Population & $\begin{array}{l}-4.137 \\
(6.362)\end{array}$ & $\begin{array}{l}3.009 \\
(6.018)\end{array}$ \\
\hline & Low Fracking*Population & $\begin{array}{l}-1.485 \\
(4.465)\end{array}$ & $\begin{array}{l}-2.133 \\
(1.515)\end{array}$ \\
\hline 3. Explanatory variable: \# of wells & \# of wells & $\begin{array}{l}0.00133 * * * \\
(0.000480)\end{array}$ & $\begin{array}{l}0.000373 \\
(0.0002)\end{array}$ \\
\hline \multirow{2}{*}{$\begin{array}{l}\text { 4. Explanatory variable: fracking } \\
\text { indicator variable cutoff at } 125 \\
\text { wells }\end{array}$} & Wells $>125$ & $\begin{array}{l}0.222 * * * \\
(0.0789)\end{array}$ & $\begin{array}{l}0.0315 \\
(0.0658)\end{array}$ \\
\hline & $0<$ Wells $<125$ & $\begin{array}{l}0.109 * * \\
(0.0536)\end{array}$ & $\begin{array}{l}-0.0127 \\
(0.0262)\end{array}$ \\
\hline \multirow[t]{2}{*}{$\begin{array}{l}\text { 5. Explanatory variable: fracking } \\
\text { indicator variable cutoff at } 25 \text { wells }\end{array}$} & Wells $>25$ & $\begin{array}{l}0.203 * * \\
(0.0967)\end{array}$ & $\begin{array}{l}0.0183 \\
(0.0516)\end{array}$ \\
\hline & $0<$ Wells $<25$ & $\begin{array}{l}0.112 * * \\
(0.0530)\end{array}$ & $\begin{array}{l}-0.0119 \\
(0.0273)\end{array}$ \\
\hline $\begin{array}{l}\text { Alternative Sample } \\
\text { 6. Eliminating NY Border Counties }\end{array}$ & High Fracking & $\begin{array}{l}0.331 * * * \\
(0.0917)\end{array}$ & $\begin{array}{c}0.0652 \\
(0.0582)\end{array}$ \\
\hline & Low Fracking & $\begin{array}{l}0.0990^{*} \\
(0.0533)\end{array}$ & $\begin{array}{l}-0.0213 \\
(0.0268)\end{array}$ \\
\hline \multirow[t]{2}{*}{$\begin{array}{l}\text { Alternative Estimation Method } \\
\text { 7. Weighted by county-year } \\
\text { population }\end{array}$} & High Fracking & $\begin{array}{l}0.202 * * \\
(0.0847)\end{array}$ & $\begin{array}{l}0.0468 \\
(0.0560)\end{array}$ \\
\hline & Low Fracking & $\begin{array}{l}0.0544 * * \\
(0.0269)\end{array}$ & $\begin{array}{l}-0.0251 \\
(0.0211)\end{array}$ \\
\hline
\end{tabular}


TABLE 5 CONTINUED

\begin{tabular}{lccc}
\hline \hline 8. Fixed Effects Poisson & High Fracking & $0.364 * * *$ & $0.063 * * *$ \\
& & $(0.0270)$ & $(0.0084)$ \\
& Low Fracking & $0.139^{* * *}$ & $-0.017 * * *$ \\
& $(0.0109)$ & $(0.0037)$
\end{tabular}

Notes: All models include county and year fixed effects and control variables 
TABle 6: PreViously Estimated Victimization Costs

Violent Crimes

Rape/Sexual Assault

$\$ 240,776$

Murder

$\$ 8,982,907$

Aggravated Assault

$\$ 107,020$

Robbery

$\$ 42,310$

Property Crimes

Burglary

$\$ 6,462$

Larceny

$\$ 3,532$

Motor Vehicle Theft

$\$ 10,772$

McCollister, K.E., M.T. French, and H. Fang. 2010. "The cost of crime to society: New crime-specific estimates for policy and program evaluation" Drug and Alcohol Dependence, 108, pg 89-109. 